\title{
DPF Systems for High Sulfur Fuels
}

\author{
Andreas C.R. Mayer \\ TTM
}

\section{Jan Czerwinski and Peter Bonsack}

AFHB

\author{
L. Karvonen \\ EMPA
}

\section{Liu Xian}

VEMC Beijing

John Mooney

John J.Mooney LLC

\begin{abstract}
During the first decade of Diesel particle filter development and deployment in cars, trucks, buses and underground sites, DPF regeneration methods were engineered that were compatible with the then prevalent high sulfur content in the fuel $>2000 \mathrm{ppm}$. The mainly used methods were burners, electrical heaters, replaceable filters and non-precious metal fuel additives. Low sulfur Diesel fuel became only available from 1996 in Sweden, 1998 in Switzerland, and after 2000 everywhere in Europe. Thus, the deployment of precious metal catalytic converters was feasible both as original equipment and retrofitting of in-use engines. The so-called CRT particle filters using PGM-catalysis for providing $\mathrm{NO}_{2}$ for low temperature regeneration became very successful wherever ULSD was available. However, in many applications, e.g. offroad and in the construction industry, Diesel engines continued to run on high sulfur fuel and in many emerging countries, even on-road Diesel fuel still contains between 1000 and 2000 ppm sulfur. These countries suffer very much from air pollution through increasing Diesel particle emissions and the high impact of black carbon particles on human health as well as on the global warming is worrying. Hence, the necessity for modern particle filters that are compatible with high sulfur content of the fuel. In the context of Chinese megalopolis, this paper reports investigation of a fuel which is typical for China
\end{abstract}

(containing $>1000 \mathrm{ppm}$ sulfur) and compares results with European standard Diesel fuel. The test objects were two modern $\mathrm{SiC}$ particle filters, which were regenerated using different iron-based FBC. The combustion attributes of the soot were investigated by TGA and their EC/OC composition was examined. The results indicate that at the given test conditions the fuel sulfur does not significantly change the filters' physical and chemical properties. Neither the filter particle loading process nor the filter regeneration is noticeably different for the high sulfur test fuel compared to the ultra-low sulfur European fuel. Therefore VERT-verified iron-based FBC-type DPF can be used in countries where ULSD is not yet available.

\section{INTRODUCTION}

Before 1990, HDV Diesel fuel in most countries contained 2000 ppm sulfur. DPF compatible with high sulfur content fuel were developed beginning 1980. These developments were documented at the annual SAE Sessions on "Diesel Particulate Emission Control" [1] from 1982 onwards. Wall flow DPFs of this development period time were already very effective. The DPF deployment however, was limited to the retrofitting of in-use engines of public transport buses, subsequently construction machines and at underground sites. New engines 
proved to be able to fulfill the legal PM mass-based emission limits of this period without a DPF and for this reason the DPF did not become yet a standard element of the OEM engine emission control technology at this time.

Low-sulfur fuels first became available from 1996 in Sweden. The main reason was the environmental impact on the Swedish lakes and forests due to $\mathrm{SO}_{2}$ emission and sulfate formation, the so-called acid-rain formation. In other European countries and Switzerland the sulfur content fell stepwise from $2000 \mathrm{ppm}$ to 500 , to $350 \mathrm{ppm}$, to $50 \mathrm{ppm}$, and then in 2002 to $10 \mathrm{ppm}$.

This was the result of the Auto Oil Programs 1 and 2, mainly driven by two arguments: first, that the sulfur in the fuel was the major factor influencing particle formation. However, this holds only true when the overall particle mass PM is collected at low temperatures, irrespective of particle size and substance and also capturing the sulfate condensate plus bound water [2]. The solid content in this particle mass PM, consisting of insoluble ultrafine carcinogenic particles is independent of sulfur. The sulfate mass on the other side plus the bound water indeed constitute the volatile phase. The Worldwide Fuel Charter [4] confirmed that fact. Today including condensates in the PM-measurement is regarded to be a measuring artefact, resulting in far too low filter efficiencies [ $\underline{3}]$ and misleading the emission technology development. This distinction between high toxic solid and low toxic volatile [21] however, was only recognized later and reflected in the European Directive EURO 6 [5] after the PMP instrumentation was implemented.

The second strong argument, which finally was decisive, was that high sulfur content in the fuel impeded the performance of precious metal catalysts. Low sulfur fuel cleared the way after 2000. It also triggered the introduction of $\mathrm{NO}_{2}$ regenerating particle filter concepts like the Johnson Matthey CRT system and the Engelhard DPX system. The DPF retrofit market using these systems steadily grew, especially for public transportation. The inherent drawback of this concept was increased $\mathrm{NO}_{2}$ emission which was underestimated and contributing to today's high $\mathrm{NO}_{2}$ levels in street canyons having intense traffics [20]. Other filter systems using burner regeneration, base metal catalysis and fuel borne catalysts $\mathrm{FBC}$ were less successful because of higher complexity, lower performance or higher cost.

ULSD fuel also permitted the use of Diesel oxidation catalytic converters. Pt-based DOC became a standard component in European LD Diesel engines, permitting EGR for NOx curtailment while diminishing $\mathrm{CO}$ and $\mathrm{HC}$. Here, too, the increasing $\mathrm{NO}_{2}$ emission was not limited. Grouping the oxides of nitrogen $\mathrm{NO}, \mathrm{NO}_{2}$ and $\mathrm{N}_{2} \mathrm{O}$ which are very different with respect to their physics and chemistry as well as to toxic effects to human, non-weighed into a single "NOx"-emission standard has blinded authority observance of emitted levels of $\mathrm{NO}_{2}$ - in contrast to occupational health where this grouping was never accepted and consequently Pt-based DOC were banned in some countries from being used in mines.
The influence of the fuel sulfur on the Pt-based catalysts is well documented [6]. With the presence of sulfur and oxygen the catalytic converter favors the conversion of $\mathrm{SO}_{2} \rightarrow \mathrm{SO}_{3}$. This tenaciously inhibits other oxidation reactions, especially the reaction $\mathrm{NO} \rightarrow \mathrm{NO}_{2}$, so that the CRT reaction finally ceases at low exhaust-gas temperatures. On the other hand, when ULSD is used the reaction $\mathrm{NO} \rightarrow \mathrm{NO}_{2}$ is favored.

Introduction of low Sulfur fuel however, remained limited. Many developing and emerging countries still use fuels with $>$ $1000 \mathrm{ppm}$ S. Even most modern industrialized countries use this high-S cheaper fuel for construction machines, non-road and stationary engines, and locomotives. Fuels in ocean shipping have even higher S concentrations up to $4 \%$. Hence, emission control has been delayed in these sectors.

Nevertheless in most countries, the off-road sector contributes as much PM as the on-road sector, because off-road emission regulation has lagged behind on-road. Consequently, the use of particle filters would be much more cost effective for off-road application.

Particle filter technology for high polluting off-road engines, burning high sulfur fuels, was therefore studied to define best available retrofit-technology for these applications. Target areas of immediate interest are underground workplaces worldwide and construction machines in France, UK, Italy, China and other countries.

As a result of these considerations all systems using precious metal catalysts and catalytic combustion had to be excluded from these high sulfur fuel applications. Burner systems, base metal coatings and fuel borne catalysts were selected as promising candidates. This study started with the investigation of two FBC systems, both based on iron.

\section{TEST ENGINE, LUBRICATION OIL AND TEST SETUP}

Table 1. Test engine Liebherr D934 S

\begin{tabular}{|l|l|}
\hline Manufacturer & Liebherr \\
\hline Type & D934S \\
\hline Cylinder volume & $6.36 \mathrm{dm}^{3}$ \\
\hline Rated speed & $2000 \mathrm{RPM}$ \\
\hline Rated power & $105 \mathrm{~kW}$ \\
\hline Max. Torque & $680 \mathrm{Nm}$ \\
\hline Model & 4 cylinder in-line \\
\hline Combustion process & Direct injection \\
\hline Injection pump & Bosch unit pump \\
\hline Supercharging & TC / IC \\
\hline Emission control & none \\
\hline Design year & 2005 \\
\hline Application & Construction machines \\
\hline
\end{tabular}


Table 2. Lubricant "Lubrizol Blue” research oil

\begin{tabular}{|l|l|l|}
\hline Viscosity kin $40^{\circ} \mathrm{C}$ & $\mathrm{ND}$ & $\mathrm{mm}^{2} / \mathrm{s}$ \\
\hline Viscosity kin $100^{\circ} \mathrm{C}$ & 13.98 & $\mathrm{~mm}^{2} / \mathrm{s}$ \\
\hline Viscosity index & $\mathrm{ND}$ & $(--)$ \\
\hline Density $20^{\circ} \mathrm{C}$ & $\mathrm{ND}$ & $\mathrm{kg} / \mathrm{m}^{3}$ \\
\hline Pour point & -25 & ${ }^{\circ} \mathrm{C}$ \\
\hline Flame point & $\mathrm{ND}$ & ${ }^{\circ} \mathrm{C}$ \\
\hline TBN & 8.4 & $\mathrm{mg} \mathrm{KOH} / \mathrm{g}$ \\
\hline Sulfur ashes & 10770 & $\mathrm{mg} / \mathrm{kg}$ \\
\hline Sulfur & 3360 & $\mathrm{mg} / \mathrm{kg}$ \\
\hline Magnesium & $<10$ & $\mathrm{mg} / \mathrm{kg}$ \\
\hline Zinc & 1200 & $\mathrm{mg} / \mathrm{kg}$ \\
\hline Calcium & 2630 & $\mathrm{mg} / \mathrm{kg}$ \\
\hline Phosphorus & ND & $\mathrm{mg} / \mathrm{kg}$ \\
\hline
\end{tabular}

$\underline{\text { Tables } 1}$ and $\underline{2}$ and Fig. 1 describe the test engine and the test set-up.

This construction engine has been repeatedly investigated during the VERT project. Several SAE papers report prior investigations on this engine $[\underline{13}, \underline{14}, \underline{17}]$. All its attributes are well known and documented. In this study, the usual exhaustgas instrumentation was enhanced with nanoparticle analysis. This comprises a SMPS system with subsequent CPC. The sampling is PMP compliant [7], i.e. the exhaust-gas sample is heated to $300{ }^{\circ} \mathrm{C}$ and diluted approx. 1:100. Hence, only solid particles are counted.

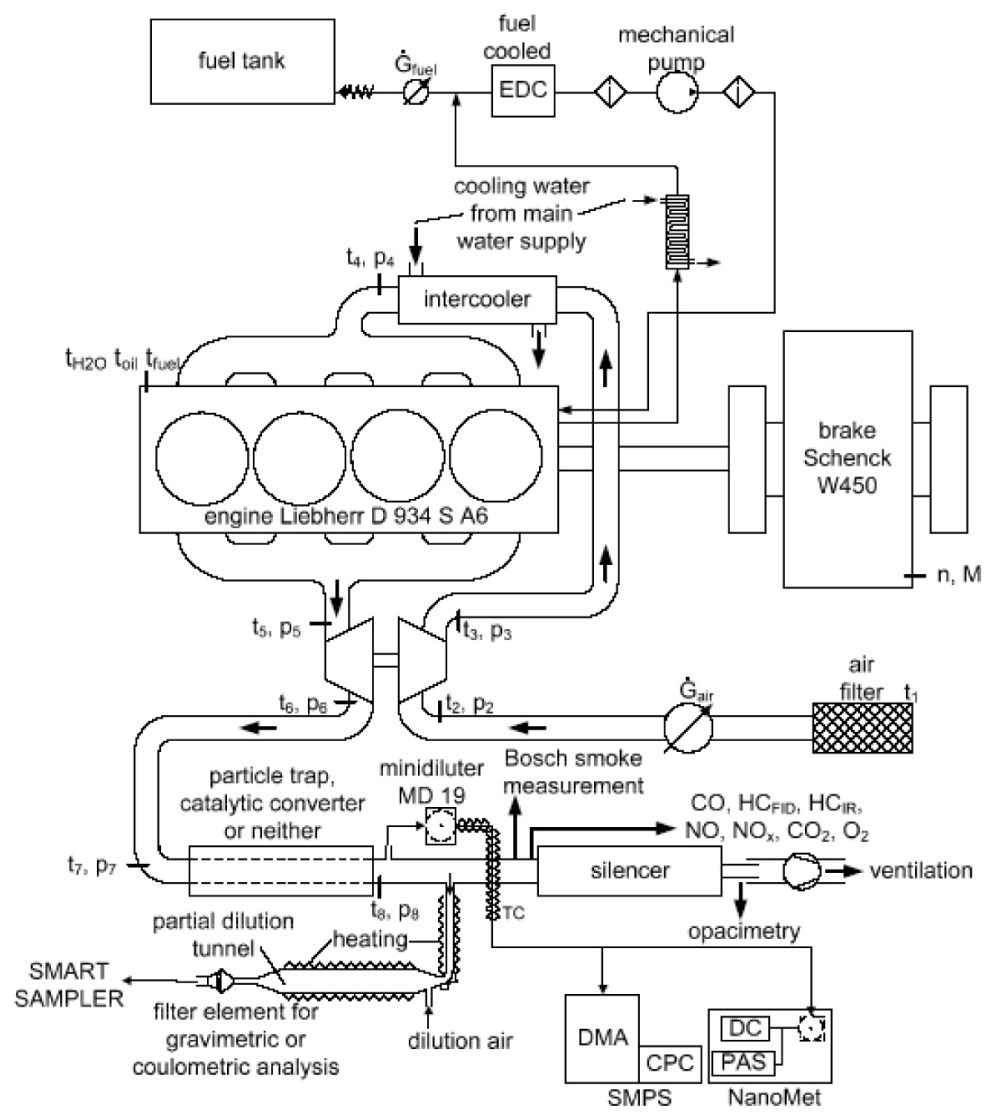

Fig. 1. Test setup [23] 


\section{TESTED FUELS}

Table 3. Properties of tested fuels compared to on HSD Chinese Fuel

\begin{tabular}{|c|c|c|c|c|c|}
\hline Type & & & Swiss market fuel & China market fuel & Test Fuel \\
\hline Manufacturer & & & Shell & Sinopec & Shell \\
\hline Property & Method & Unit & \begin{tabular}{|l|} 
ULSD, \\
SN $181160-1-2009$
\end{tabular} & $\begin{array}{l}\text { HSD } \\
\text { China Fuel Sample }\end{array}$ & $\begin{array}{l}\text { HSD } \\
\text { Formulated }\end{array}$ \\
\hline Density (at $15^{\circ} \mathrm{C}$ ( & EN ISO 12185 & $\mathrm{~kg} / \mathrm{m}^{3}$ & 825.2 & 848.6 & 841.8 \\
\hline Viscosity $\left(\right.$ at $\left.40^{\circ} \mathrm{C}\right)$ & EN ISO 3104 & $\mathrm{~mm}^{2} / \mathrm{s}$ & 2.199 & 2.733 & 2.083 \\
\hline Cetane number & ISO 5165 & - & 49.9 & 45.8 & 45.3 \\
\hline Cetane index & ISO 4264 & - & 51.8 & ND & ND \\
\hline Sulfur content & EN ISO 20846 & $\mathrm{mg} / \mathrm{kg}$ & 7.7 & 1223 & 1369 \\
\hline Cloud point & ISO 3015 & ${ }^{\circ} \mathrm{C}$ & -11 & ND & ND \\
\hline Pour point (CFPP) & EN 116 & ${ }^{\circ} \mathrm{C}$ & -23 & ND & ND \\
\hline Flash point & EN ISO 2719 & ${ }^{\circ} \mathrm{C}$ & 56.0 & ND & ND \\
\hline Heating value & & $\mathrm{MJ} / \mathrm{kg}$ & $\min .42 .5$ & ND & ND \\
\hline Aromatic hydrocarbons & ISO 3837 & Vol \% & $\max .2$ & ND & ND \\
\hline Boiling analysis $\left(340^{\circ} \mathrm{C}\right)$ & EN ISO 3405 & Vol \% & 96.1 & 91.1 & 94.4 \\
\hline Ash & EN ISO 6245 & $\mathrm{mg} / \mathrm{kg}$ & $<0.001$ & $<0.001$ & $<0.001$ \\
\hline Fe of additized fuel & SPO 631 & $\mathrm{mg} / \mathrm{kg}$ & $18.7 / 18.1$ & ND & $18.5 / 18.1$ \\
\hline
\end{tabular}

The original Chinese fuel could not be exported from China to the Swiss engine lab. Hence the Chinese fuel was analyzed and Shell formulated a similar fuel, which was used in the tests reported here. The comparison shows that the Chinese Diesel fuel is very similar to the European, except for the sulfur content, and is not contaminated with more organic or inorganic components.

\section{TESTED PARTICLE FILTERS}

Both tested filter systems are VERT certified [ $[$ ].

Table 4. Tested particle filter systems

\begin{tabular}{|c|c|c|c|}
\hline Manufacturer & & Dinex A/S & Pirelli Eco Technology S.p.A. \\
\hline Material & & $\mathrm{SiC}$ & $\mathrm{SiC}$ \\
\hline Porosity & {$[\%]$} & 45 & 42 \\
\hline Pore size & {$[\mu \mathrm{m}]$} & 15 & 20 \\
\hline Cell number & [CPSI] & 150 & 180 \\
\hline Wall thickness & {$[\mathrm{mm}]$} & 0.7 & 0.43 \\
\hline Space velocity & {$\left[\mathrm{s}^{-1}\right]$} & 30.2 & 22.8 \\
\hline Regeneration & & FBC passive & FBC active \\
\hline Manufacturer of FBC & & Innospec & Pirelli Eco Technology \\
\hline Specification & & Satacen ${ }^{\circledR} 4$ & CAM-FBC active \\
\hline FBC content max. & & $20 \mathrm{mg} \mathrm{Fe} / \mathrm{kg}$ fuel & $20 \mathrm{mg} \mathrm{Fe} / \mathrm{kg}$ fuel \\
\hline
\end{tabular}




\section{ANALYTICAL METHODS}

\section{GRANULARITY ANALYSIS}

The size classification of the solid soot particles was determined using the SMPS procedure (Scanning Mobility Particle Sizer) [9]. The particle classification and particle counting was done after heating the gas sample to a temperature of $300^{\circ} \mathrm{C}$ and diluting approx. 1:100 (PMP compliant [7]). Thus only solid particles entered the instrumentation. The size classification is in very narrow bands, between $10-500 \mathrm{~nm}$ in 60 size classes. The defined particle size corresponds to the particle mobility diameter and is therefore representative for diffusion processes. This classification corresponds to deposition in the human respiratory system and penetration through the alveolar membrane [19]. The particle number concentration is quantified in a condensation core counter using the individual counting mode. The SMPS instrumentation from TSI with DMA 3081 and CPC 3772 were used.

\section{THERMOGRAVIMETRIC ANALYSIS (TGA)}

Soot was sampled at an average temperature of $320^{\circ} \mathrm{C}$, diluted by the SmartSampler tunnel and thereby cooled to a temperature of $25-30^{\circ} \mathrm{C}$ at which temperature it was deposited on a quartz fiber filter for the thermogravimetric analysis.

The thermo-gravimetric procedure is well known and documented [10]. This investigation used the STA 409 CD instrument from Netzsch and a quadrupole mass spectrometer Aëolos, also from Netzsch, Germany. The measurements were done in pure oxygen atmosphere at a heating rate of $20^{\circ} \mathrm{C} / \mathrm{min}$. in the temperature range of $40^{\circ} \mathrm{C}-800^{\circ} \mathrm{C}$. The mass spectrometer was used to detect online the emission of the following substances:

- Water

- $\mathrm{CO}, \mathrm{CO}_{2}$,

- $\mathrm{SO}, \mathrm{SO}_{2}$

\section{EC/OC ANALYSIS}

The separation of the intercepted soot (again sampled on a quartz fiber filter) in elemental carbon EC and organic carbon $\mathrm{OC}$ indicates the character of the soot. It is an essential metric of the combustibility. Pure elemental carbon requires substantially higher combustion temperatures than a mixture with high organic content. The analysis was done using both the classical Coulometry (according to the German Standard VDI 2465) and also the NIOSH method 5040 [11]. The distinction $\mathrm{EC} / \mathrm{OC}$ is also important in this investigation because in occupational health the Diesel particle emissions are usually evaluated according to its EC content [12].

\section{RESULTS}

\section{RESULTS OF THE ENGINE TESTS}

\section{Comparison at Steady-State Point $1400 \mathrm{rpm}$ and $340 \mathrm{Nm}$}

At this medium load point, the engine is measured with respect to all limited emissions and thermodynamic data as usual. The main results are summarized in Table 5 .

With the exception of PM, the emissions are measured steady state as legally prescribed. The data are reported, as usual, energy specific in $[\mathrm{g} / \mathrm{kWh}]$ terms. $\mathrm{PM}[\mathrm{g} / \mathrm{kWh}]$ could not be determined in these tests, because particle samples had to be collected for subsequent TGA- and EC/OC-analysis. The reported $\mathrm{PM}[\mathrm{g} / \mathrm{filter}]$ data correspond to the loading cycle as described in Fig.4. There is no significant disparity in the Table 5 gaseous emissions and in the fuel consumption. The particle mass PM is higher for the tests with iron additive, as expected.

\section{Particle Size Analysis in the Raw Gas} (Without DPF)

$\underline{\text { Figures } 2}$ and $\underline{3}$ summarize size analysis with all 4 fuels at the operating point at $1400 \mathrm{RPM}$ and $340 \mathrm{Nm}$.

Table 5. Limited emissions CO, HC, NOx, fuel consumption and PM

\begin{tabular}{|l|c|c|c|c|c|}
\hline & CO & HC & NOx & Fuel Consumption & PM \\
\hline & {$[\mathrm{g} / \mathrm{kWh}]$} & {$[\mathrm{g} / \mathrm{kWh}]$} & {$[\mathrm{g} / \mathrm{kWh}]$} & {$[\mathrm{g} / \mathrm{kWh}]$} & {$[\mathrm{g} /$ filter $]$} \\
\hline ULSD & 0.62 & 0.25 & 6.79 & 227.4 & 2.2 \\
\hline HSD & 0.69 & 0.24 & 7.49 & 227.9 & 2.17 \\
\hline ULSD + FBC & 0.65 & 0.26 & 6.82 & 230.3 & 2.6 \\
\hline HSD + FBC & 0.65 & 0.26 & 7.28 & 229.0 & 2.41 \\
\hline
\end{tabular}




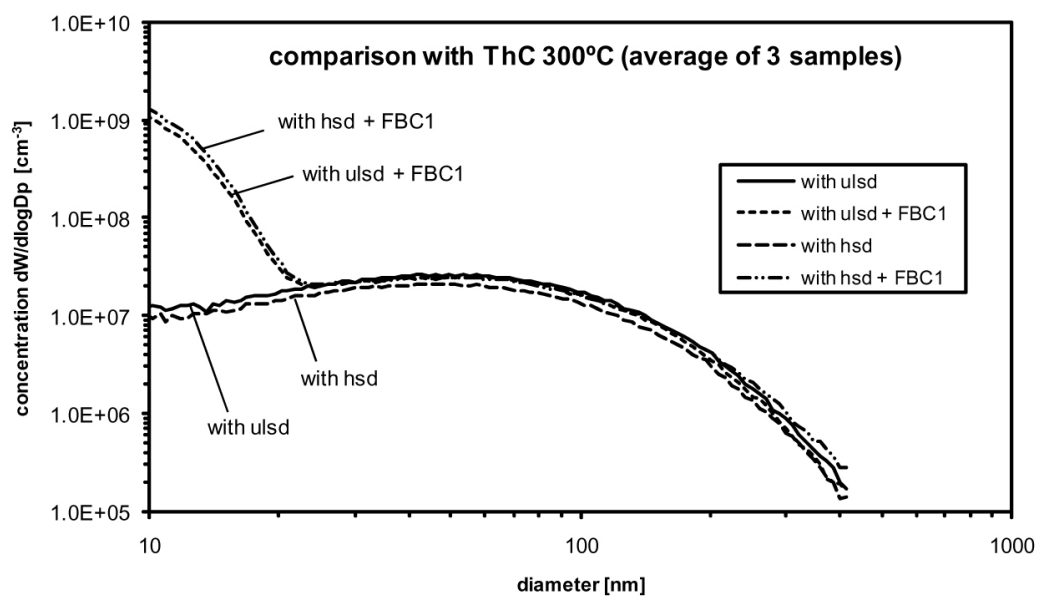

Fig. 2. Size distribution comparing the 4 fuel variants with gas sample pre-heating to $300^{\circ} \mathrm{C}$, as per $\mathrm{PMP}[7]$

The size distribution reveals almost no difference for the 4 fuel variants. The iron additive causes the expected increase of particle count in the range $10-25 \mathrm{~nm}$. These are ultra fine iron oxide clusters formed after combustion of the metal organic additive substances. These very fine particles result in a large specific surface that promotes catalytic effects during the filter regeneration. VERT certified DPF systems very efficiently intercept these fine FBC oxide particles as they remove all solid particles including metal oxide particles from engine wear and lubrication oil by over $99 \%$ [23] to an extent that they are usually not detectable in the size spectrum after the DPF [13]. The filtration attributes of these two VERT-certified DPF are well documented [ $[$ ] $]$. Hence, size measurements were not done after the DPF.

The measurements were repeated with sample heating to only $100^{\circ} \mathrm{C}$.
This investigation was done to observe the condensate formation. $100^{\circ} \mathrm{C}$ is far below the condensation point of sulfuric acid vapors. Sulfur contained in exhaust-gas, at temperatures below $300^{\circ} \mathrm{C}$, usually generates a distinct bimodal size distribution with exceptionally high peaks [14]. This investigation surprisingly found no condensate in the cool sample. With Pt-catalysis, sulfates would be formed according to the processes: $\mathrm{SO}_{2}+1 / 2 \mathrm{O}_{2} \rightarrow \mathrm{SO}_{3}$ and with the water present in the exhaust: $\mathrm{SO}_{2}+8 \mathrm{H}_{2} \mathrm{O}+1 / 2 \mathrm{O}_{2} \rightarrow \mathrm{H}_{2} \mathrm{SO}_{4}+7 \mathrm{H}_{2} \mathrm{O}$, which explains the high contribution to PM mass. Apparently the exhaust-gas did not contain $\mathrm{SO}_{3}$ and hence sulfuric acid was not formed. The sulfur in the fuel was obviously completely converted to $\mathrm{SO}_{2}$ and passed the system as gas, without forming sulfates.

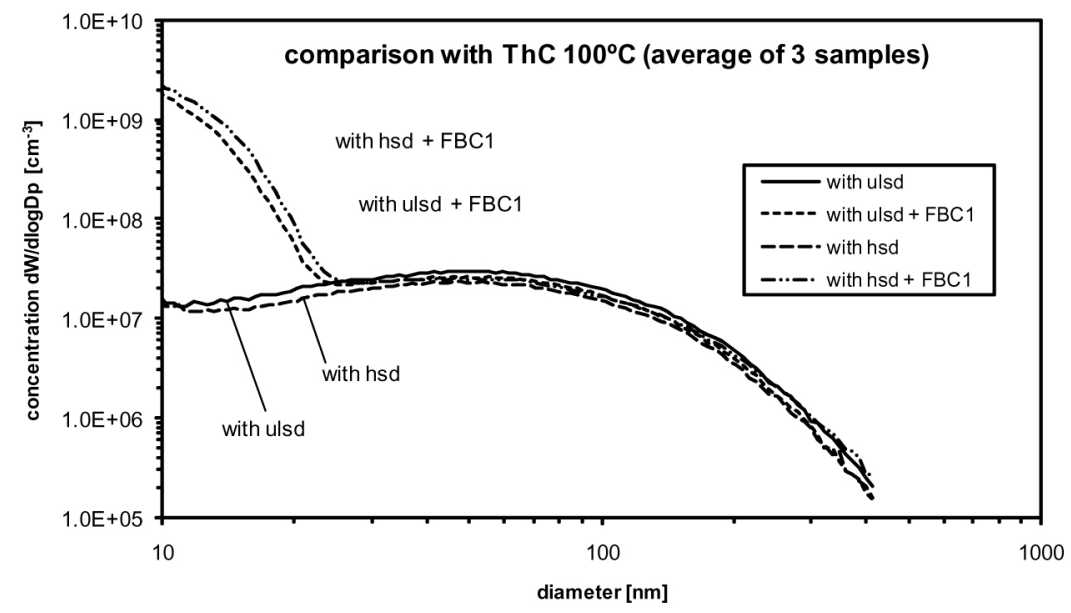

Fig. 3. Size distribution comparing the 4 fuel variants with the gas sample pre-heated to only $100^{\circ} \mathrm{C}$ in order to provoke sulfuric condensates 


\section{Filter Loading and Regeneration}

The filters became soot-loaded in a dynamic cycle as illustrated in Figure 4. Soot was generated in rapid acceleration cycles from idling until full load, thus avoiding the temperature rising to values at which the FBC doped fuel would trigger filter regeneration. The aim was to attain the highest possible filter loading to subsequently test the regeneration response.

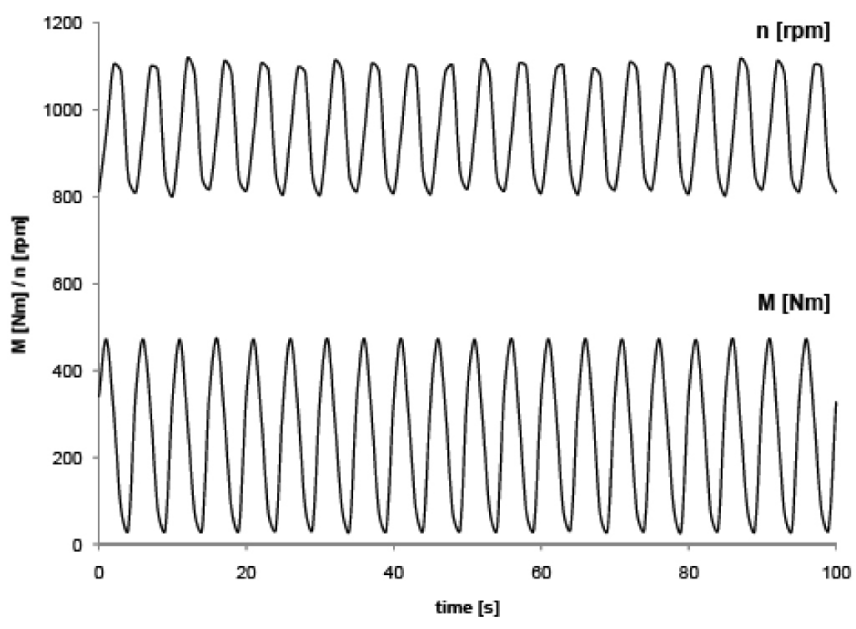

Fig. 4. Filter loading cycle
The exhaust backpressure rise, during filter loading, was not uniform for all fuels. This can be explained as follows: the test started with a new filter, which after regeneration still had some residual soot load. The second loading cycle thus has a distinctly different character and cannot be compared with the first. This will be further investigated at a later stage of this investigation.

\section{Regeneration Response}

The filter loaded with soot in the described cycle, was regenerated according to the Swiss standard test protocol SNR 277205 [15]. This test was only performed for the two FBC doped fuels. The results are shown in Fig. 5 and Fig. 6.

The regeneration begins below $340^{\circ} \mathrm{C}$ exhaust-gas temperature. The load is increased every 20 minutes until full load. Plotted are the temperatures T7 before DPF and T8 after DPF, torque, pressure loss across the filter $\Delta \mathrm{p} 7$ and the particle emission in the $\mathrm{CPC}$ count.

The results (for two different DPF, two different additives but both iron-based and both $20 \mathrm{ppm}$ dosage) show that, already at the first operating point, the back-pressure decreased despite increasing soot load and increasing volume throughput. Already at this $340^{\circ} \mathrm{C}$ temperature, the balance-point is passed.

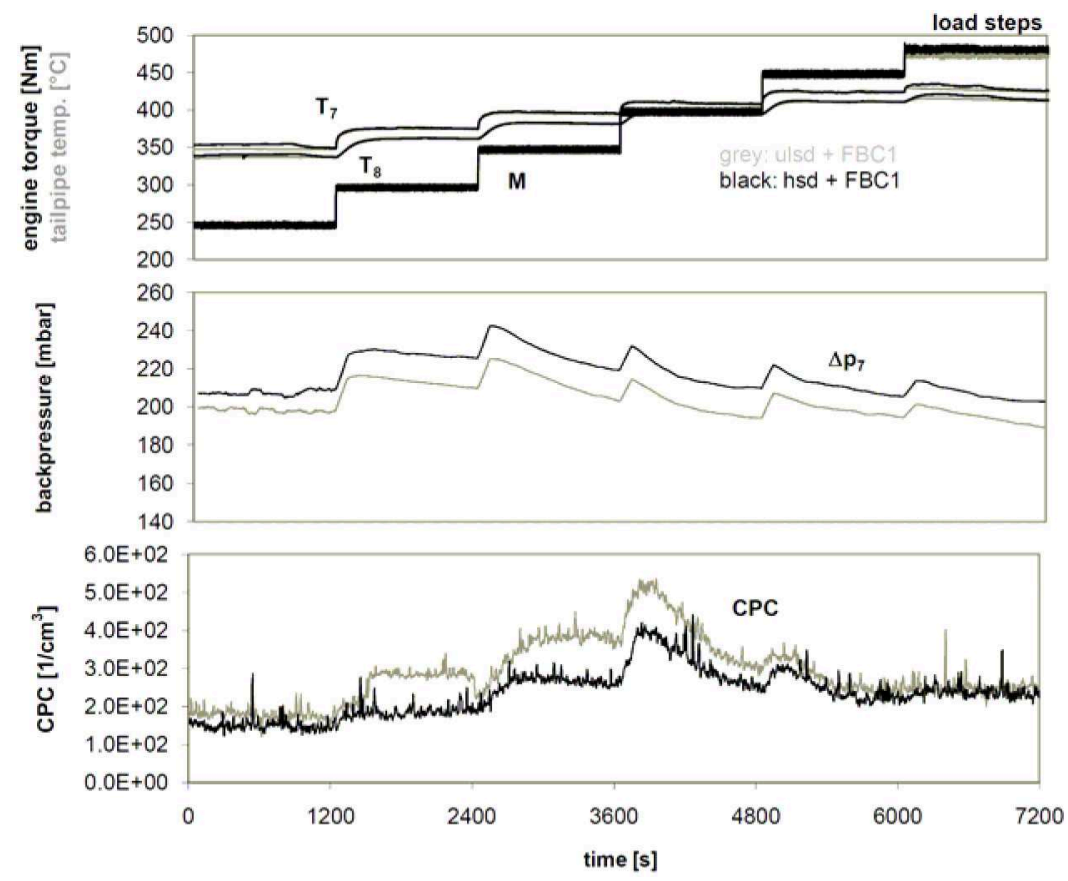

Fig. 5. Regeneration of the Dinex filter. ULSD and HSD, both with FBC 


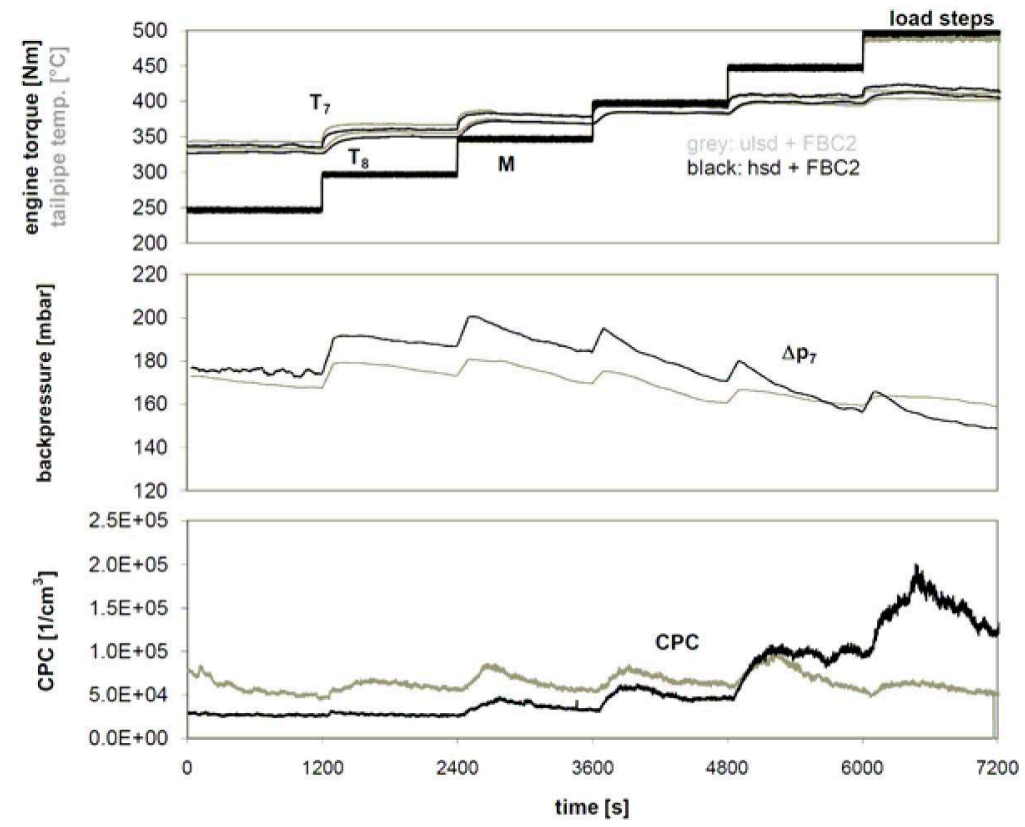

Fig. 6. Regeneration of the Pirelli filter. ULSD and HSD, both with FBC

Increasing the temperature steepens the regeneration gradient until termination of the test after running 20 minutes at full load. The regeneration is obviously not yet complete, as evident in the gradients. Hence, the next test starts with slightly different initial conditions. Despite this imperfection of the test procedure, there is almost no evident difference between the two fuels.

The difference of the two CPC plots seems somehow striking: whereas the Dinex is in the range of $10^{2}$ particles per cc, Pirelli is in the range of $10^{5}$. This should be compared to the raw emission (See Fig 2) which is in the range of $10^{7}$. In other words: while Dinex shows filtration efficiencies of $>99.99 \%$ in this test the Pirelli filter "only" shows $99 \%$. The difference in pore size and wall thickness may contribute to this difference but also slightly different soot layer thickness could explain most of it. It should be emphasized here that these VERTcertified filters keep filtration of solid ultrafine particles to a level of $>99 \%$ even during regeneration.

\section{THERMOGRAVIMETRIC ANALYSIS}

The entire investigation comprised four fuel variants. Fig. 7 with thermo-gravimetric data, coupled with simultaneous MSdetection of volatile combustion products $\left(\mathrm{H}_{2} \mathrm{O}, \mathrm{CO}, \mathrm{CO}_{2}, \mathrm{SO}\right.$, $\mathrm{SO}_{2}$ ) only compares ULSD to HSD, both with FBC. The grey line pertains to data for ULSD. The black line pertains to data for HSD, which is the test fuel having high sulfur content. Charted as a function of the increasing temperature are: mass loss and ion current, water vapor, $\mathrm{CO}, \mathrm{CO}_{2}, \mathrm{SO}, \mathrm{SO}_{2}$
Ion-currents recorded for the observed volatile decomposition products are proportional to the volume portion of the decomposition product in the TG exhaust. The lower figure shows the sulfur decomposition products at a higher resolution.

The response is surprisingly similar for the low-sulfur and the high-sulfur fuel. The similarity prevails for the emission of water vapor and the first drying phase, at temperatures above $100^{\circ} \mathrm{C}$, and also for the initiation of soot combustion evidenced by spikes of $\mathrm{CO}$ and $\mathrm{CO}_{2}$. Very remarkable is the response of gaseous sulfur emissions $\mathrm{SO}$ and $\mathrm{SO}_{2}$. These emissions are exceptionally low, in the entire temperature range, including the gradual increase during soot combustion. Noteworthy is that combustion of the high sulfur fuel soot does not produce more $\mathrm{SO}$ and $\mathrm{SO}_{2}$ emissions. This investigation thus confirms that the high sulfur content does not proportionally deposit on the soot, but obviously exits the system as gaseous $\mathrm{SO}_{2}$.

Figure 8 is another interesting comparison. It shows the thermo-gravimetric analysis for the effects of the fuel additive on the regeneration.

Evidently, the FBC triggers the start of regeneration at about $340{ }^{\circ} \mathrm{C}$, which is $160 \mathrm{~K}$ below the temperature the soot is starting to burn without FBC support and thereby enables faster and more complete filter regeneration, which however, is not visible in this diagram. 

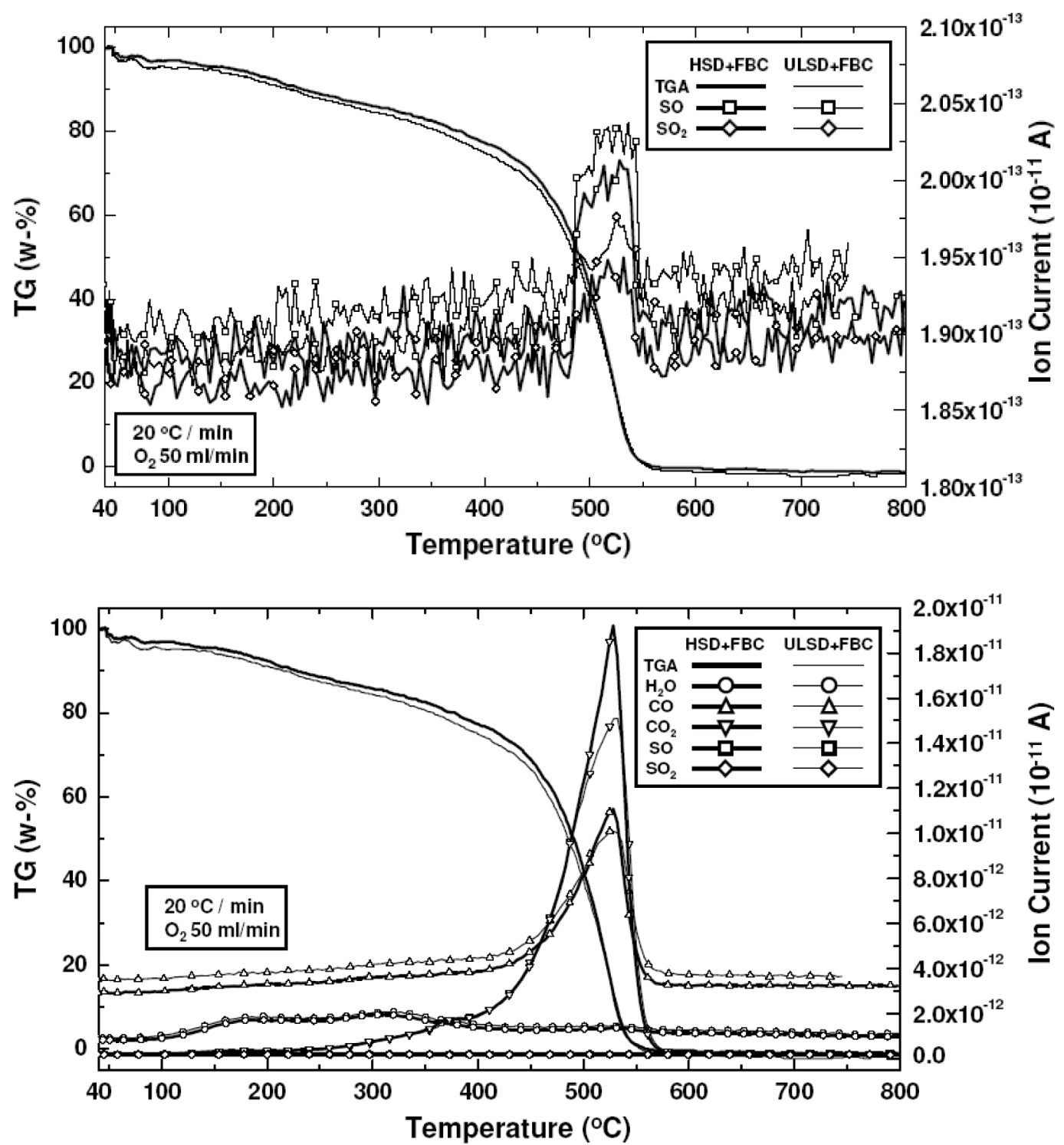

Fig. 7. Comparison of the TG-MS data recorded for ULSD and HSD; both with 20 ppm iron additive

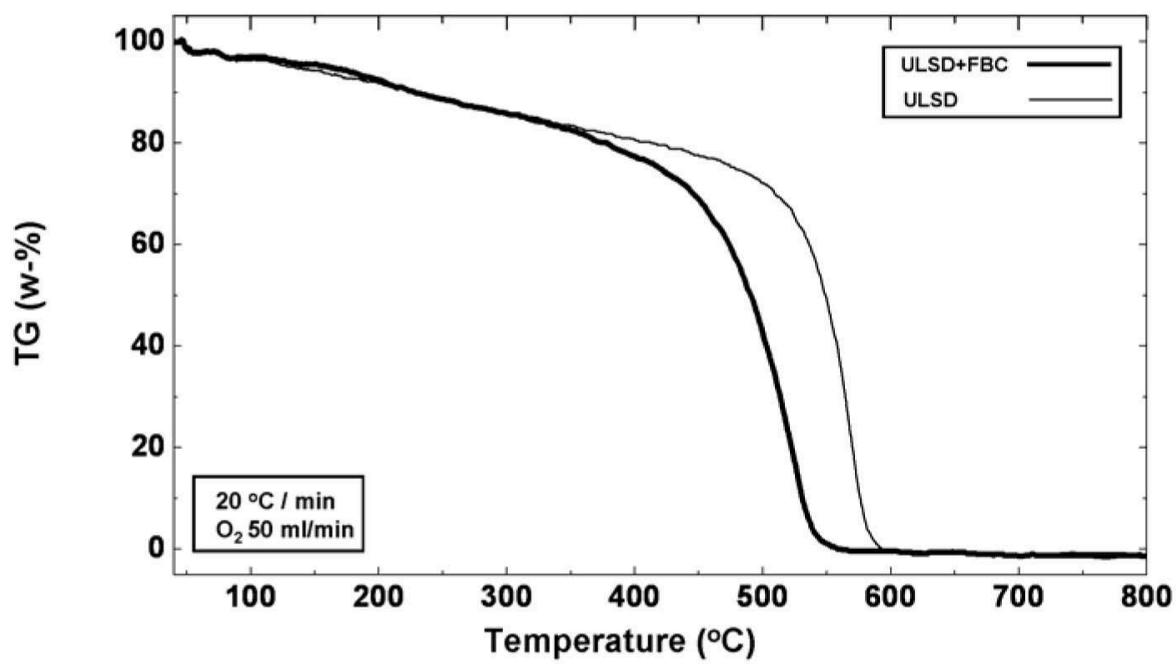

Fig. 8. TGA analysis for the ULSD fuel with and without iron FBC 


\section{$\mathrm{EC} / \mathrm{OC}$}

During filter loading according to Fig.4, samples are collected on quartz filters. These samples are analyzed using the Coulometry procedure VDI 2465 as well as the NIOSH procedure [11]. Table 6 summarizes the results: regenerated. This ensures durable and dependable operation. These conclusions are of course limited to short term effects and to the operation profiles used during this investigation. Further investigations will be required.

Table 6. EC/OC analysis of soot samples from filter loading test

\begin{tabular}{|l|c|c|c|c|c|c|}
\hline \multirow{2}{*}[\mu\mathrm{g}/\text{filter}]{} & \multicolumn{3}{|c|}{ Coulometry VDI 2465 } & \multicolumn{3}{c|}{ NIOSH 5040 [11] } \\
\cline { 2 - 7 } & OC & EC & EC/TC & OC & EC & EC/TC \\
\hline ULSD & 212 & 1838 & $89.7 \%$ & 205 & 1905 & $90.3 \%$ \\
\hline HSD & 236 & 1750 & $88.1 \%$ & 238 & 1849 & $88.6 \%$ \\
\hline ULSD + FBC & 307 & 2193 & $87.7 \%$ & 409 & 2157 & $84.1 \%$ \\
\hline HSD + FBC & 279 & 1893 & $87.1 \%$ & 317 & 1882 & $82.5 \%$ \\
\hline Blind value & 44 & 26 & - & 50 & 4 & - \\
\hline
\end{tabular}

The data listed for OC and EC are the absolute mass per filter sample. This mass naturally differs from case to case. These absolute values are therefore not mutually comparable. Instead, the ratio of elemental carbon $\mathrm{EC}$ to total carbon $\mathrm{TC}=\mathrm{EC}+\mathrm{OC}$ is compared for both measurement procedures. Despite the inevitable measurement variability, the results are very uniform. Hence, there is no identifiable disparity between the fuel variants. The HSD data tends to a slightly lower EC/TC ratio, but the differences are rather insignificant.

\section{CONCLUSION}

This investigation compared 2 DPF-systems using iron based FBC-regeneration with European Diesel fuel (sulfur content $<$ $10 \mathrm{ppm}$ ) and high sulfur test fuel (sulfur content $1369 \mathrm{ppm}$ ) as it is typically used in China. No significant differences were found in the limited emissions $\mathrm{CO}, \mathrm{HC}, \mathrm{NOx}$ and PM, the $\mathrm{EC} /$ $\mathrm{OC}$ ratio of the soot, in the characteristics of residual soot combustion (TGA) and the regeneration response. Evidently, the FBC iron-oxide enables that the sulfur (both in the fuel and in the lube oil) entering combustion subsequently exits as gaseous $\mathrm{SO}_{2}$. No sulfate is formed and thus the particle formation is unaffected. In contrast to this: whereas when a precious metal catalyst is deployed with high sulfur fuel, $\mathrm{SO}_{2}$ can be converted to $\mathrm{SO}_{3}$ as published in [16], [17], [18] and [20] - thus sulfate is formed, which increases the particle mass and inhibits filter regeneration. Consequently, precious metal DOC and Pt-coated DPF are unsuitable for HSD fuels. But particle filter systems without catalytic attributes, or with base metal catalysts, can perfectly cope with very high sulfur fuel content. The soot particles are efficiently filtered, without undesirable side-effects, and the filters are effectively

\section{ACKNOWLEDGEMENT}

This investigation was performed within the scope of a SinoSwiss project. It studied the particle filter technology for offroad deployment in Chinese cities. The authors are grateful to the SDC (Swiss Agency for Development and Cooperation), VECC (Chinese Vehicle Emission Control Center), BJEPB (Beijing Environment Protection Bureau), the filter manufacturers PIRELLI and DINEX and the VERT-network (Association of BAT Particle Filter producing companies) for helping to finance the tests and for the agreement to publish the results.

\section{CONTACT INFORMATION}

Andreas Mayer

TTM

Fohrhölzlistrasse $14 \mathrm{~b}$

CH-5443 Niederrohrdorf

ttm.a.mayer@bluewin.ch

\section{REFERENCES}

1. Diesel Particulate Emission Control, SP-537, SAE International Congress, Detroit, Feb. 28, 1983

2. Mayer, A., Einfluss des Treibstoffs auf die Grössenverteilung ultrafeiner Partikel bei Dieselmotoren Technische Akademie Esslingen, $2^{\text {nd }}$ Colloquium Fuels, 20./21.1.1999

3. Song, J., Alam, M., Zello, V., Boehman, A.L. et al., "Fuel Sulfur Effect on Membrane Coated Diesel Particulate Filter," SAE Technical Paper 2002-01-2788, 2002, doi:10.4271/2002-01-2788. 
4. Worldwide Fuel Charter, September 2006; www. autoalliance.org

5. Euro $5 / 6$ for emissions of light passenger and commercial vehicles: EC-Regulation No. 715/2007,

6. Allansson, R. et al., The Use of the Continuously

Regenerating Trap (CRT ${ }^{\mathrm{TM}}$ ) to Control Particulate

Emissions: Minimizing the Impact of Sulfur Poisoning, SAE 2002-01-1271

7. UN-ECE R83 annex 4 Appendix 5

8. VERT ${ }^{\circledR}$ Filter List, October 2010, www.vert-certification.eu

9. Kasper, M., "The Number Concentration of Non-Volatile Particles - Design Study for an Instrument According to the PMP Recommendations," SAE Technical Paper 2004-01-0960, 2004, doi:10.4271/2004-01-0960.

10. Jaenicke-Rössler, K. and Leitner, G; TA-MS for high temperature materials. Thermochimica Acta 295 (1997) 133-145 (Elsevier)

11. Birch, M.E. and Cary, R.A., Elemental Carbon-Based Method for Monitoring Occupational Exposures to Particulate Diesel exhaust, Aerosol Science and Tech., 68(3): 1996

12. Grenzwerte am Arbeitsplatz 2007, Suva, Schweizerische Unfallversicherungs-Anstalt, Nr. 1903.d www.suva.ch/waswo

13. Mayer, A., Ulrich, A., Czerwinski, J., Matter, U. et al., "Retention of Fuel Borne Catalyst Particles by Diesel Particle Filter Systems," SAE Technical Paper 2003-01-0287, 2003, doi:10.4271/2003-01-0287.

14. Mayer, A., Kasper, M., Matter, U., Neue Wege zur Charakterisierung der Dieselpartikelemissionen, Dresdner Motorenkolloquium, 20./21. Mai 1999

15. SNR 277205, Testing of Particle Filter Systems for Internal Combustion Engines, www.bafu.admin.ch/ partikelfilterliste

16. Hansen, Ken Friis et al., DTI, Large-scale project with particulate filters on heavy-duty vehicles in Odense, June 2002, ISBN Nr.: 87-90661-31-1

17. Mayer, A., Ulrich, A., Heeb, N.V., Czerwinski, J. et al., "Particle Filter Properties after 2000 hrs Real World Operation," SAE Technical Paper 2008-01-0332, 2008, doi:10.4271/2008-01-0332.

18. Bémer, D., Depay, J.-P., Lauzier, F., Emission Diesel performances des filtres à particules pour engines non routiers, INRS Hygiène et sécurité du travail, $1^{\text {er }}$ trimestre 2010

19. Oberdörster, G. et al., Nanotoxicology, an Emerging Discipline Evolving from Studies of Ultrafine Particles. Environmental Health Perspective, July 2005

20. Maricq, M. et al., The effects of the catalyst and fuel sulfur on PM-emissions. HEI Annual Conference 2009.
21. Cascio, W.E., Environmental health effects of combustion-related ultrafine particulate matter, ETH conference on combustion generated nanoparticles, 2010; www.nanoparticles.ethz.ch

22. Czerwinski, J., Zimmerli, Y., Mayer, A., Heeb, N. et al., "Testing of Combined DPF+SCR Systems for HD-retrofitting - VERT dePN,” SAE Technical Paper 2009-01-0284, 2009, doi:10.4271/2009-01-0284.

23. Mayer, A.C., Ulrich, A., Czerwinski, J., and Mooney, J.J., "Metal-Oxide Particles in Combustion Engine Exhaust,"

SAE Technical Paper 2010-01-0792, 2010, doi:10.4271/2010-01-0792.

\section{ACRONYMS AND ABBREVIATIONS}

\section{AFHB}

University of Applied Sciences, Biel, Switzerland

BM

Base Metal

CPC

Condensation Particle Counter

CPSI

Cells per square inch

CRT

Continuously Regenerating Trap (trademark Johnson Matthey)

DC

Diffusion Charger

DOC

Diesel Oxidation Catalyst

DMA

Differential Mobility Analyser

DPF

Diesel Particle Filter

DPX

Catalyst coated DPF (trademark Engelhard)

EC

Elemental Carbon

EGR

Exhaust Gas Recirculation

\section{EMPA}

Eidgenössische Material Forschungs- und Prüfanstalt, Dübendorf, Switzerland 


\section{EN, ISO, SN}

Standards: European Norm, International Standard, Swiss Norm

\section{FBC}

Fuel Borne Catalyst

HSD

High sulfur diesel

LD

Light duty

MS

Mass spectrometry

nm

Nanometer $=10^{-9} \mathrm{~m}$; vóvvo $($ greek $)=$ the dwarf

\section{NIOSH}

National Institute for Occupational Safety and Health

NO

Nitrogen monoxide

$\mathrm{NO}_{2}$

Nitrogen dioxide

OC

Organic carbon

PAS

Photoelectric Aerosol Sensor

PGM

Platinum Group Metals

PM

Particulate matter

PMP

Particle Measurement Program ppm

Parts per million

$\mathbf{S}$

Sulfur

$\mathrm{SO}, \mathrm{SO}_{2}$

Suflur oxides

\section{SMPS}

Scanning Mobility Particle Sizer (Instruments TSI, USA).

TGA

Thermogravimetric analysis

TC

Total Carbon $=\mathrm{EC}+\mathrm{OC}$

ThC

Thermo-Conditioning $=$ preheating of the gas sample line

TTM

Technik Thermische Maschinen, Consulting Switzerland

\section{ULSD}

Ultra low Sulfur Diesel

VDI

Association of German Engineers

VEMC

Vehicle Emission Management Center, Beijing

VERT $^{\circledR}$

Verification of Emission Reduction Technologies, a trade mark
The Engineering Meetings Board has approved this paper for publication. It has successfully completed SAE's peer review process under the supervision of the session organizer. This process requires a minimum of three (3) reviews by industry experts.

All rights reserved. No part of this publication may be reproduced, stored in a retrieval system, or transmitted, in any form or by any means, electronic, mechanical, photocopying, recording, or otherwise, without the prior written permission of SAE.

ISSN 0148-7191
Positions and opinions advanced in this paper are those of the author(s) and not necessarily those of SAE. The author is solely responsible for the content of the paper

SAE Customer Service:

Tel: 877-606-7323 (inside USA and Canada)

Tel: 724-776-4970 (outside USA)

Fax: 724-776-0790

Email: CustomerService@sae.org

SAE Web Address: http://www.sae.org

Printed in USA 